\title{
Influence of Entrepreneurship Education on Employment Quality and Employment Willingness
}

\author{
https://doi.org/10.3991/ijet.v16i16.24897 \\ Chunxu Jia, Jialin Zuo, Wei Lu( $\left.{ }^{(}\right)$ \\ Hebei Jiaotong Vocational and Technical College, Shijiazhuang, China \\ lu0727lu@126.com
}

\begin{abstract}
The entrepreneurship education of college students is an educational practice to train comprehensive talents with entrepreneurship qualities, who are willing and confident of employment and could conform to the needs of social development. Focusing on the entrepreneurship education of ordinary college students, this paper probes deep into the status quo of entrepreneurship education among college students, and thoroughly analyzes how this education model influences the employment quality and employment willingness of college students. The results show that: a good entrepreneurship education obviously enhances the employment quality of college students, and apparently boosts their employment willingness; entrepreneurship education guides the cognition of college students through multiple means, and promotes their employment ability. The research lays the basis for active exploration into to employment quality and employment willingness of college students.
\end{abstract}

Keywords-entrepreneurship education, employment willingness, entrepreneurship qualities, employment quality, employment ability

\section{Introduction}

The entrepreneurship education of college students is an education form that cultivates college students' entrepreneurship ability and quality [1, 2]. It aims at improving students' self-employment ability, developing their basic entrepreneurship ability and quality, and cultivating high-quality modern socialist builders with innovative spirit and entrepreneurial ability [3, 4]. Entrepreneurship education not only trains students' entrepreneurial skills and knowledge, but also builds their ideological and political thinking and values [5]. At present, the main teaching methods of entrepreneurship education of college students are theoretical teaching, practical teaching, and experiential teaching $[6,7]$.

Statistics and surveys on the employment quality and employment willingness of college students revealed that, innovation and entrepreneurship education is a must and it's necessary to actively provide new impetus for the training of high-quality professionals with both innovative spirit and entrepreneurial competence [8]. Entrepreneurship education started very late in China, but it develops fast and now people are attaching greater importance to it $[9,10]$. The entrepreneurship education in China is 
classified into three types: the balanced entrepreneurship education mode dedicated to cultivating versatile entrepreneurs, the professional entrepreneurship education mode dedicated to cultivating elite entrepreneurs, and the applied entrepreneurship education mode dedicated to cultivating pragmatic entrepreneurs $[11,12]$. Now the college students' employment quality is gradually enhancing over the years and their employment willingness is boosting. The entrepreneurship education of college students has obviously realized the transformation of higher education, promoted the growth of college students, improved their employment quality, and broadened their employment ideas $[13,14]$.

Undergraduate entrepreneurs are the objects of entrepreneurship education, they benefit from it, if they want to succeed in the fierce market competition, they must cooperate with higher educational schools in entrepreneurship education [15]. The implementation of entrepreneurship education helps student entrepreneurs seek a broader path to start their business, makes them better and more actively adapt to the requirement of market economy, allocates the resources more reasonably, and cultivates more competitive entrepreneurs $[16,17]$. This study takes current entrepreneurship education among college students as the research object, it deeply probes into the status quo of college students' entrepreneurship education, and analyzes the influence of entrepreneurship education on the employment quality and employment willingness of college students, in the hopes of providing a basis for the research on college students' employment quality and employment willingness.

\section{Status Quo of Entrepreneurship Education in Ordinary Higher Educational Schools in China}

\subsection{Survey purposes and targets}

The development of entrepreneurship education in China has undergone three phases: the initial exploration phase, the steady advancement phase, and the in-depth development phase $[18,19]$. Entrepreneurship education is an education form that combines theory with practice, wherein the practice is an important link in entrepreneurship education, and enhancing this link can consolidate college students' entrepreneurial knowledge, stimulate their career vitality, and strengthen their entrepreneurial ability $[20,21]$. In this study, a few colleges students from Nanchang University in Jiangxi Province were taken as subjects, and a questionnaire survey was conducted to investigate their entrepreneurship education. A total of 400 copies were sent out, and 389 valid questionnaires were returned. Table 1 lists the basic information of the questionnaire. Figure 1 gives the curriculum system of the entrepreneurship education of college students. Courses in the curriculum system are divided into a few categories, including basic practical courses, innovative research courses, autonomous practical courses, student development courses, and innovative coaching courses. 
Table 1. Basic information of the questionnaire

\begin{tabular}{|l|l|c|c|}
\hline & & Number & Percentage/\% \\
\hline \multirow{3}{*}{ Gender } & Male & 210 & $53.98 \%$ \\
\cline { 2 - 4 } & Female & 179 & $46.02 \%$ \\
\hline \multirow{3}{*}{ Science students } & Yes & 246 & $63.24 \%$ \\
\cline { 2 - 4 } & No & 143 & $36.76 \%$ \\
\hline \multirow{3}{*}{ Academic level } & Undergraduate & 311 & $79.95 \%$ \\
\cline { 2 - 4 } & Specialist & 78 & $20.05 \%$ \\
\hline & First grade & 77 & $19.79 \%$ \\
\cline { 2 - 4 } & Second grade & 102 & $26.22 \%$ \\
\cline { 2 - 4 } & Third grade & 104 & $26.74 \%$ \\
\cline { 2 - 4 } & Fourth grade & 106 & $27.25 \%$ \\
\hline
\end{tabular}

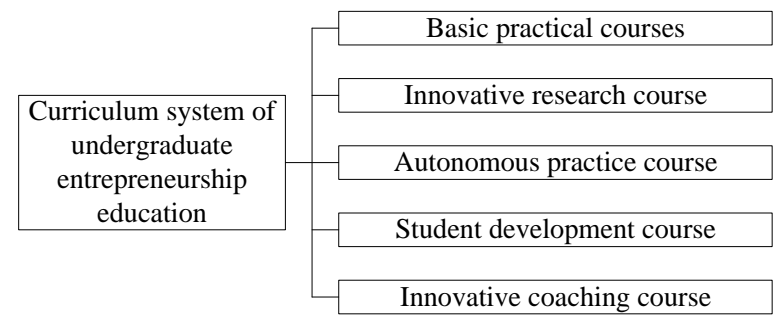

Fig. 1. Curriculum system of entrepreneurship education of college students

\subsection{Survey results and analysis}

Chinese higher educational schools have attached their importance to the development progress of entrepreneurship education, the support of relevant policies, and the effective implementation of entrepreneurship education [22]. Numerous studies have proved that effective education system and education mode can indeed improve the effectiveness of entrepreneurship education [23, 24]. Figure 2 shows the statistics of students' understanding of the concept of entrepreneurship education. Nearly $80 \%$ of the students think that starting a career is called entrepreneurship, and a small proportion of students think that starting a business, developing a cutting-edge science project, or working part-time during school time can also be called entrepreneurship. Figure 3 shows the statistics of students' prediction of the success rate of entrepreneurship, more than $95 \%$ of the respondents think that the success rate is very low or not high. Figure 4 shows the statistics of students' most important demand for starting a business, a strong personal will ranks the first, followed by investor's investment, research results or patents of individuals or teams, and the training service provided by schools or the society. Figure 5 shows the statistics of college students' satisfaction with the entrepreneurial atmosphere. $25.92 \%$ of the respondents are very satisfied with current entrepreneurial atmosphere on campus, $47.22 \%$ are satisfied, only $5.18 \%$ are not satisfied. Figure 6 shows the statistics of college students' demand for entrepreneurial abilities. From 
high to low, the results are social competence, managerial ability, psychological quality, creative ability, and technical ability.

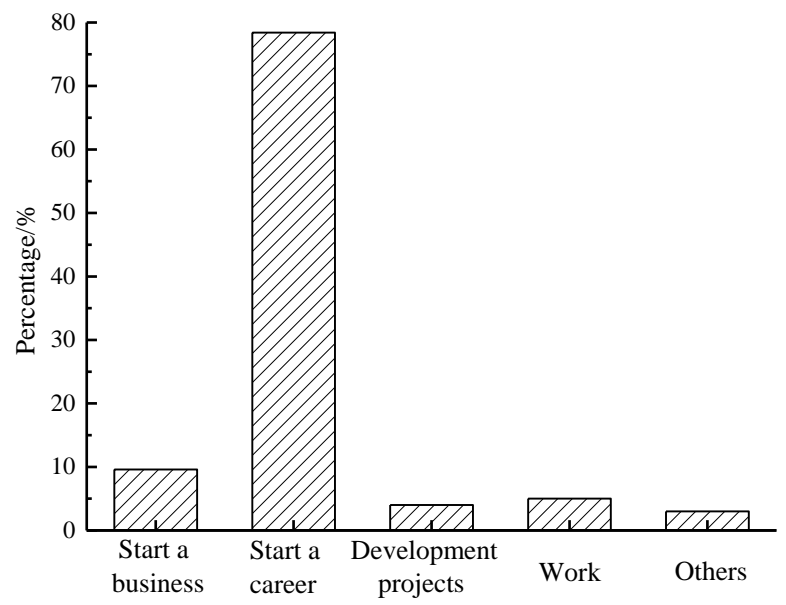

Fig. 2. Statistics of students' understanding of the concept of entrepreneurship education

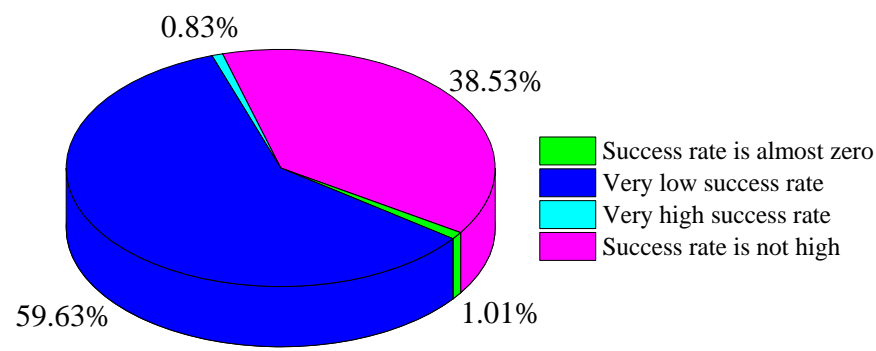

Fig. 3. Statistics of students' prediction of the success rate of entrepreneurship

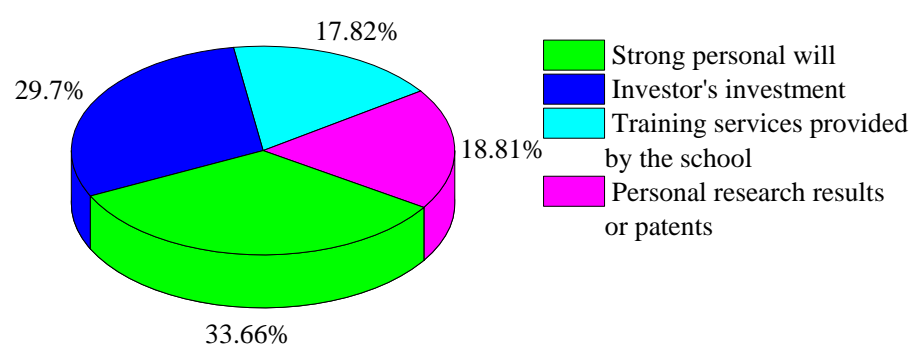

Fig. 4. Statistics of students' most important demand for starting a business 


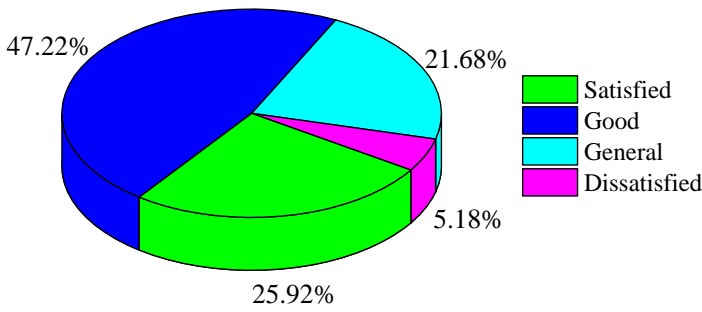

Fig. 5. Statistics of college students' satisfaction with the entrepreneurial atmosphere

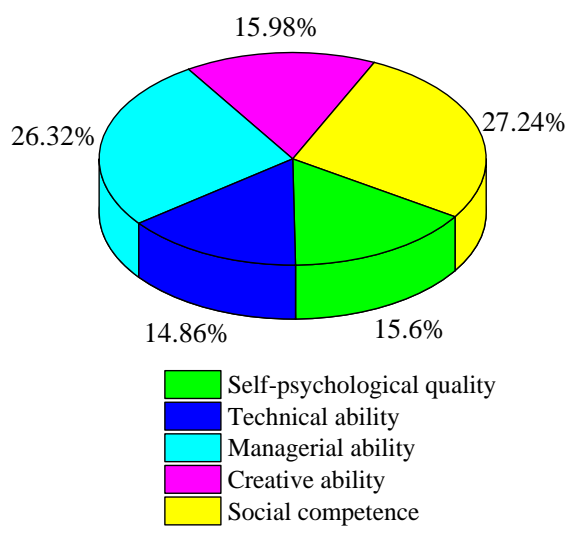

Fig. 6. Statistics of college students' demand for entrepreneurial abilities

\section{Problems and Countermeasures}

The survey also revealed that the entrepreneurship education of Chinese college students has obtained certain achievements, and students generally express a positive and active attitude towards it. However, a few problems exist in the aspects of entrepreneurship motivation, entrepreneurship education effectiveness, entrepreneurial value guidance, and social support. Figure 7 lists the specific problems in college students' entrepreneurship education, the first is the inadequate ability in entrepreneurship cognition, including the low interest in entrepreneurship, insufficient motivation of entrepreneurship, incompetent entrepreneurial ability, and low participation in entrepreneurial practice. The second is the inapparent entrepreneurship education effect, which mainly manifested as the loose integration of entrepreneurship education and ideological and political education, the imbalanced faculty structure of entrepreneurship education, and the deficient entrepreneurship education methods and modes [25]. Third, the problems in students' entrepreneurial values are prominent, which exhibit as over-expectation of students for entrepreneurship, weak sense of integrity and responsibility, and the common tendency of utilitarianism and money worship [26, 27]. Fourth, the entrepreneur- 
ship education of college students lacks effective support, which reflected as the incomplete entrepreneurship support system, and the imperfect entrepreneurship guarantee mechanism [28].

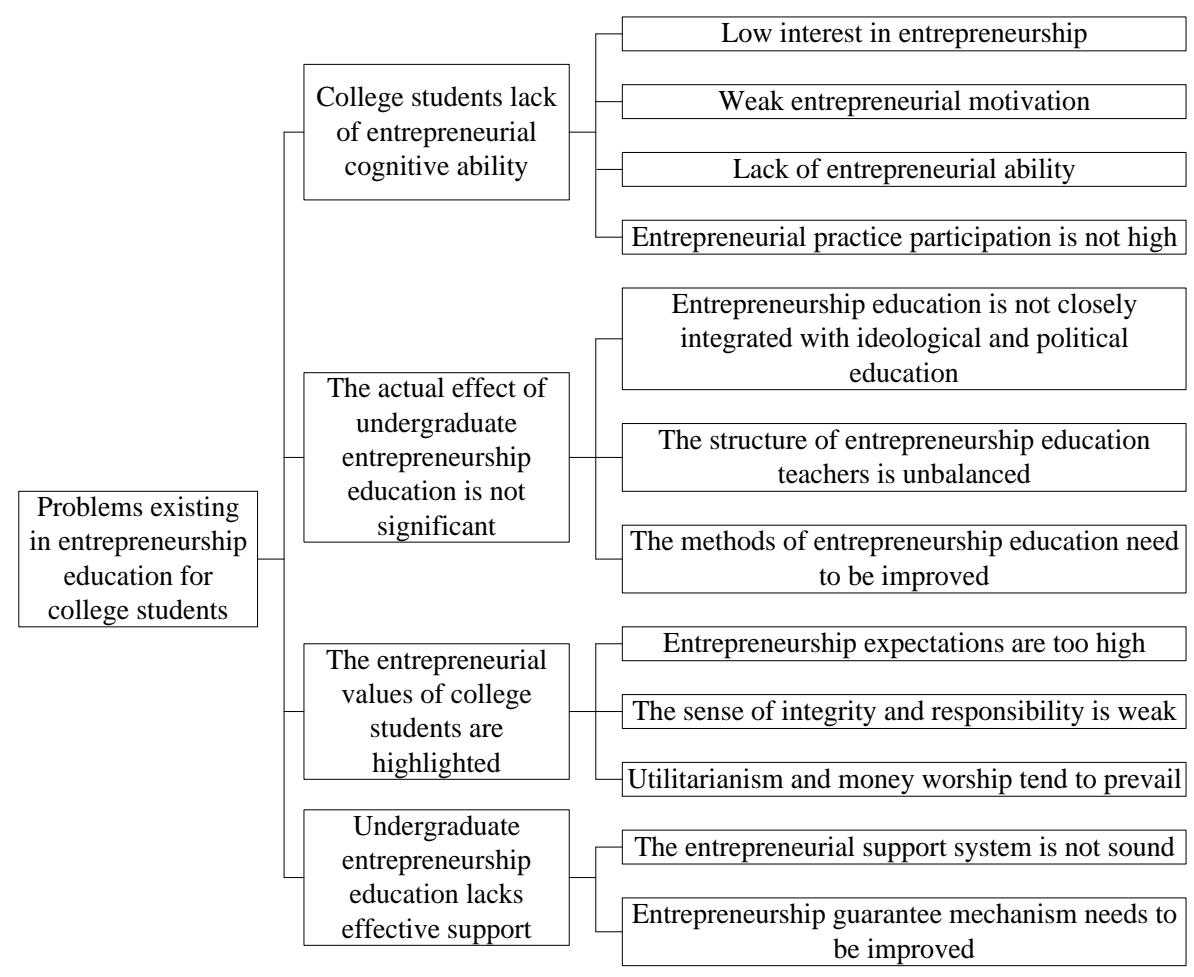

Fig. 7. Specific problems in college students' entrepreneurship education

Figure 8 gives the causes of the problems in the entrepreneurship education of students in ordinary colleges and universities. The first cause is the insufficient national policy publicity of entrepreneurship, the publicity effect is not good, the channels of policy publicity for encouraging college students to start a business is obstructed, and the responsibilities of policy publicity executors are overlapped with each other [29, 30]. The second cause is the insufficient social support for entrepreneurship education, the imbalance of economic and social development level weakens the effectiveness of college students' entrepreneurship education, and the overall entrepreneurial atmosphere of the society is not ideal [31,32]. The ideas of college students' entrepreneurship education need to be transformed, the current ideas are outdated, and the resources of entrepreneurship education in colleges and universities lack effective integration and optimization. The students' family members haven't given enough attention to the entrepreneurship education of college students, their families' attitudes toward entrepreneurship education are quite different. Moreover, students' cognitions of entrepreneurship, psychological quality levels, and cognition ability levels vary greatly from person to person [33]. 


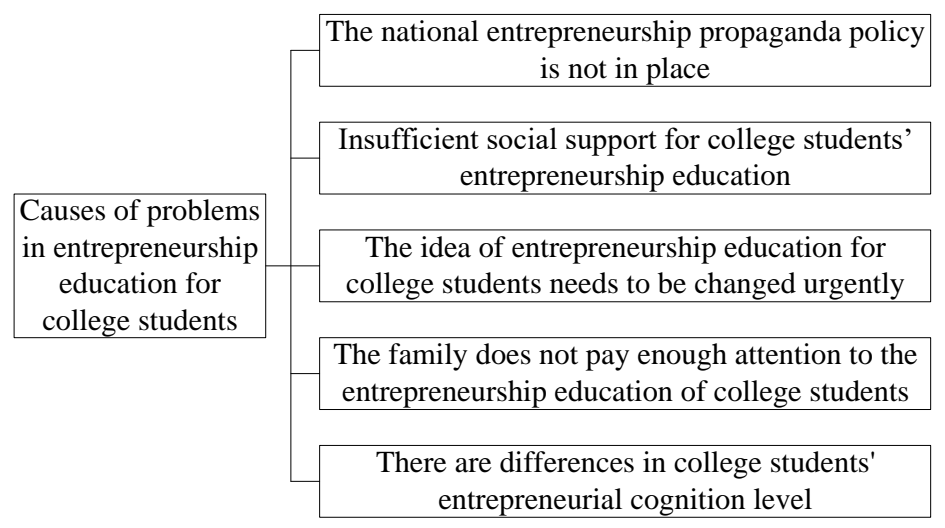

Fig. 8. Causes of problems in the entrepreneurship education of college students

To well solve the problems in college students' entrepreneurship education, first, its' necessary to form scientific goals of entrepreneurship education and focus on the cultivation of entrepreneurial spirit and psychological quality [34]; second, its' necessary to establish a set of scientific and sound organizational structure and system, improve the faculty's comprehensive level, teaching ability, and scientific research ability; third, it's necessary to build a set of systematic evaluation mechanism for entrepreneurship education, and a sound service system for the entrepreneurship education of college students [35].

\section{$4 \quad$ Value Orientations of Entrepreneurship Education}

The value of entrepreneurship education is the core for educators to clarify the goals of education and development. Figure 9 shows the model of the employment and entrepreneurship education of college students. The cultivation of employment and entrepreneurship abilities consists of three parts: knowledge education, simulation training, and entrepreneurial practice. Knowledge education includes: theoretical knowledge learning, thinking training, skill training, and experience learning. Simulation training includes: employment and entrepreneurship competitions, practice platform training, and school instructions and training, etc. Entrepreneurial practice includes: general core competence training, professional core competence training, practical competence training, and entrepreneurial competence training, etc. Figure 10 shows the value orientations of college students' entrepreneurship education, which have four aspects: pay attention to the all-round development of college students; focus on the unity of knowledge and action; highlight personalized education; strengthen the core literacy of college students. Figure 11 presents the goals of entrepreneurship education for college students, the first goal is to cultivate and shape students' entrepreneurial spirit, including: cultivate students' thinking and innovative awareness; cultivate students' self-challenging and volitional quality; cultivate students' social responsibility to serve the people. The second goal is to cultivate students' entrepreneurial abilities, which include the professional knowledge and skills, work capability, and social communication ability, 
etc. The third goal is to cultivate students' cognition and identification of entrepreneurial values, which means to build correct cognition of entrepreneurial values in students, the identification of entrepreneurial values should adhere to the unity of unification and diversification, and the entrepreneurship education should cultivate college students to have the awareness of entrepreneurial value identification. The fourth goal is to inherit and create entrepreneurial culture, which means to cultivate students' ability to sense traditional culture and understand mainstream entrepreneurial culture. The entrepreneurship education of college students should follow certain principles, such as the principle of integrating the education for all students with the classified education for part students, the principle of integrating entrepreneurship education with value guidance, and the principle of integrating theoretical teaching with practical training, and so on.

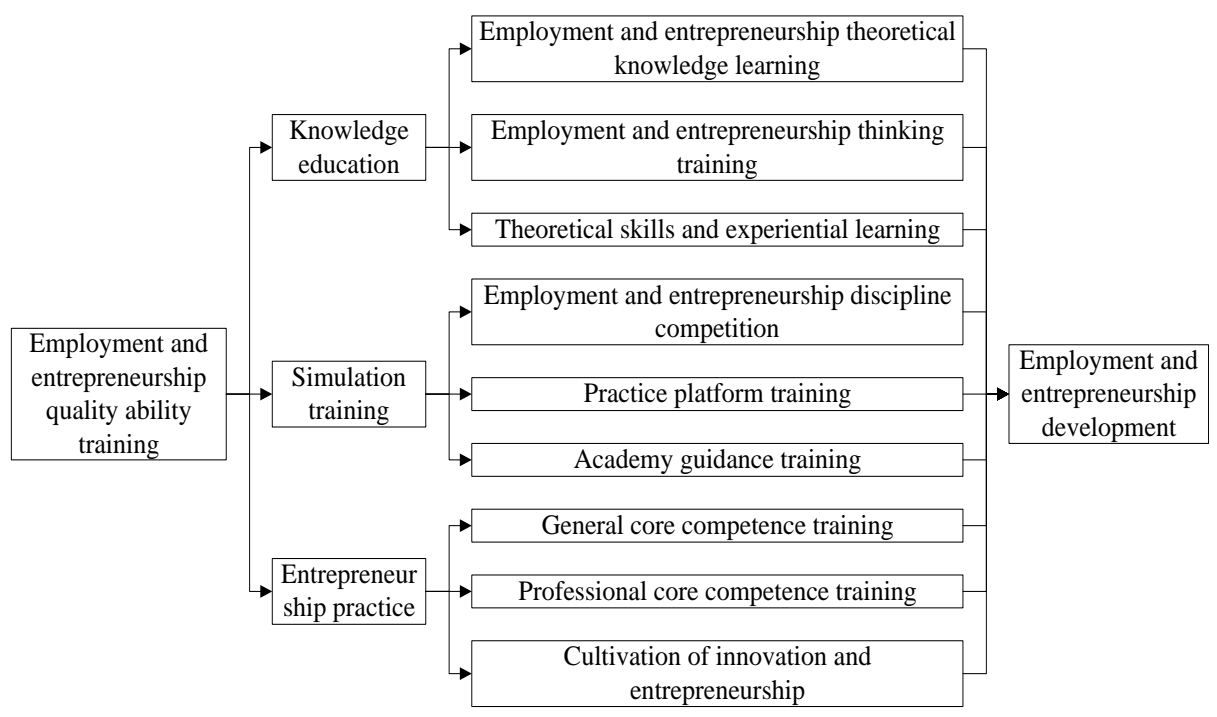

Fig. 9. Employment and entrepreneurship education model for college students

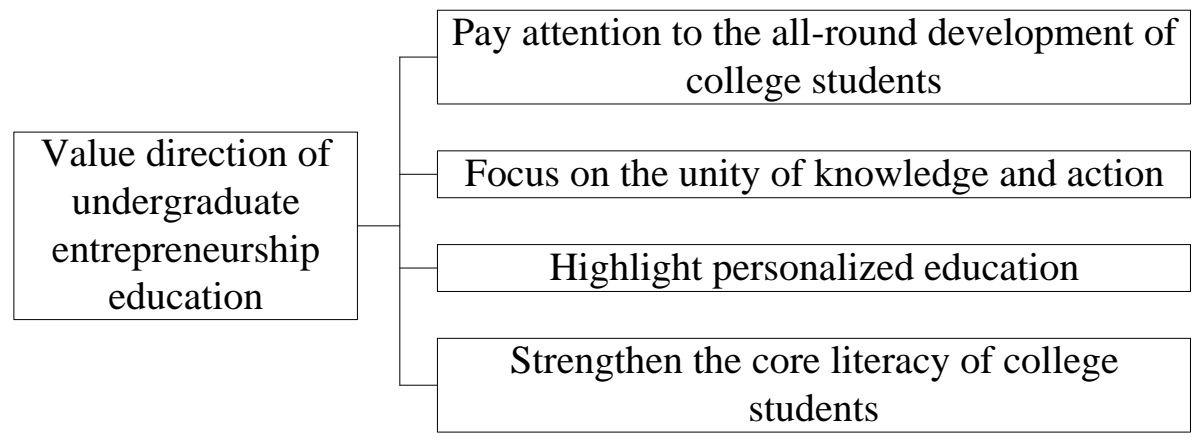

Fig. 10.Value orientations of college students' entrepreneurship education 


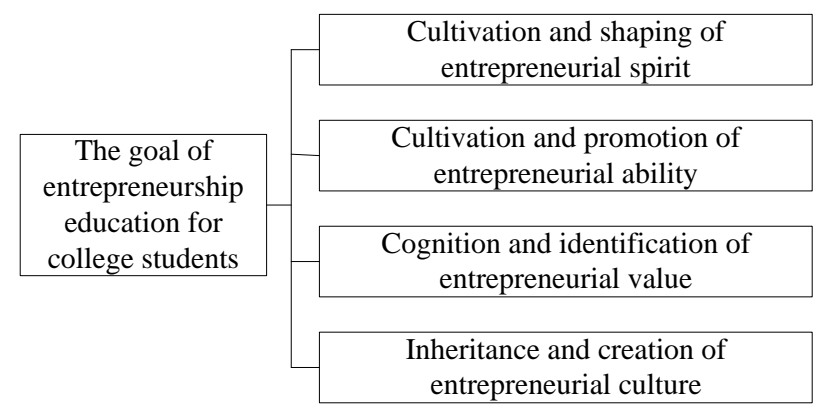

Fig. 11.Goals of entrepreneurship education for college students

\section{$5 \quad$ Influence of Entrepreneurship Education on Employment Quality, Ability, and Willingness of College Students}

Entrepreneurship education and employment quality could complement each other, and the entrepreneurship education is related to the professional education of college students. Entrepreneurship education has a significant positive influence on the employment quality of college students, and professional education also has a significant positive influence on it. Figure 12 shows a diagram of the government-school-enterprise tripartite cooperation mode. In this cooperation mode, school provides entrepreneurial knowledge education, government provides guarantee for entrepreneurship, and enterprise provides entrepreneurial skill education. School responds to government's calls, government provides guidance for enterprise, and school provides knowledge education for enterprise. Figure 13 is a framework of the influence mechanism of entrepreneurship education on the employability of college students. In ordinary schools, employability is related to the statistical data of the employment situations in schools, and the entrepreneurship education is conducive to the cultivation of college students' employability. Entrepreneurship education is generally carried out based on multi-platform simulation, outside the classrooms, students apply the knowledge they learnt to practice, cognize, practice again, and cognize again, thereby realizing the comprehensive training of their professional knowledge and skills. The forward-looking feature of entrepreneurship education could assist college students establish ideas of innovation, improve employability, and guide cognition using multiple methods.

The employability of college students is consisted of several dimensions, including: professional application ability, professional innovation ability, learning ability, selfmanagement ability, communication and coordination ability, and teamwork ability. In terms of the influencing factors of employment quality and employment willingness, a good entrepreneurship education has a promotive effect on improving college students' employment quality; for college students, the mastery of basic professional knowledge and skills takes the dominant position and it is irreplaceable. Entrepreneurship education can help college students understand the professional knowledge they have learned from all angles, inspire their exploration spirit, and promote their innovative ability. Moreover, a good entrepreneurship education also has an obvious promotive 
effect on college students' employment willingness. The organic integration of entrepreneurship education should give every aspect its due and promote the entrepreneurship education in colleges and universities as a whole, and only in this way can the employability of college students be enhanced more quickly.

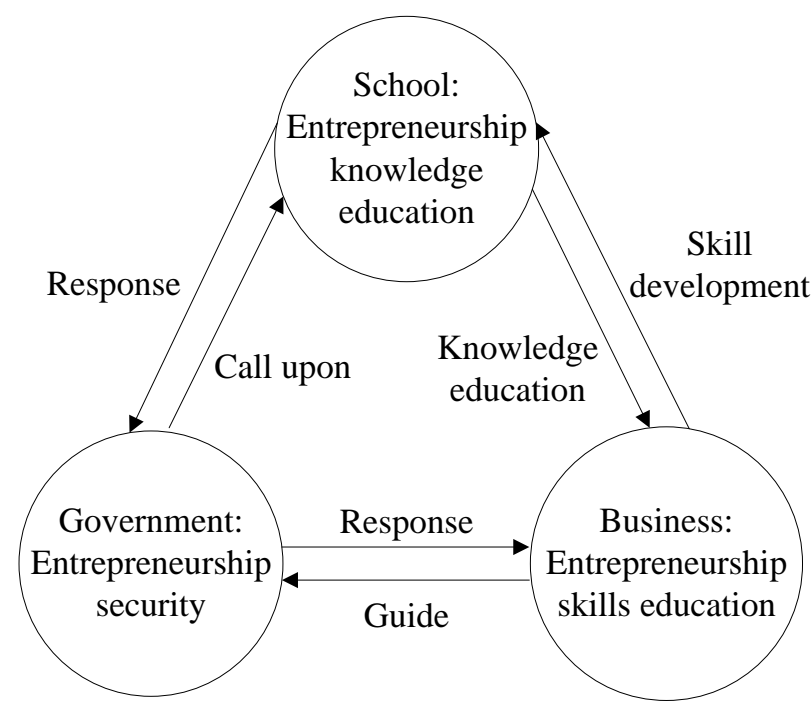

Fig. 12.Government-school-enterprise tripartite cooperation mode

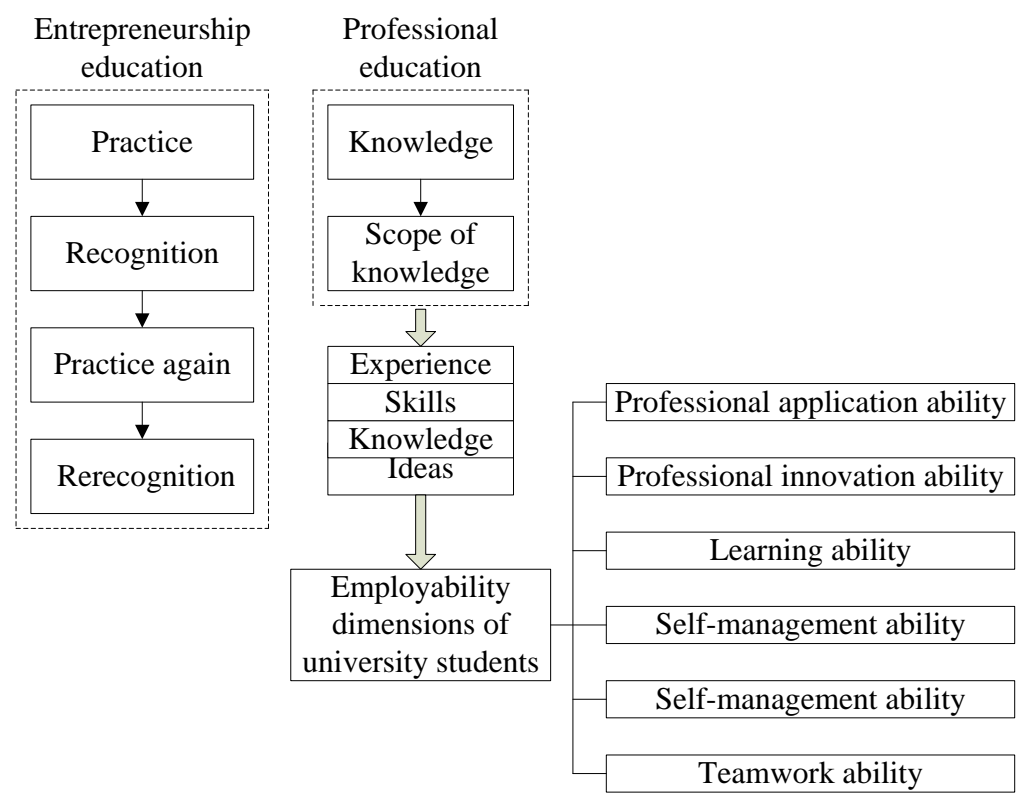

Fig. 13. Framework of the influence mechanism of entrepreneurship education on the employability of college students 


\section{Conclusions}

This paper researched the entrepreneurship education of students in ordinary Chinese higher educational schools, it probed deep into the status quo of college students' entrepreneurship education and analyzed its influence on the employment quality and employment willingness of college students. The specific conclusions are as follows:

1. From high to low, the college students' demands for entrepreneurial abilities are: social competence, managerial ability, psychological quality, creative ability, and technical ability.

2. At present, the problems in students' entrepreneurial values are prominent, and the causes of these problems can be attributed to the country's entrepreneurship policy, the schools' educational ideas, and the students' individual cognition levels. To solve these problems, its' necessary to form scientific goals of entrepreneurship education and focus on the cultivation of entrepreneurial spirit and psychological quality, and establish a set of scientific and sound organizational structure and system and a set of systematic and complete evaluation mechanism for entrepreneurship education.

3. Entrepreneurial ability includes professional knowledge and skills, work capability, social communication ability, as well as the cognition and identification of the value of entrepreneurship.

4. The employability of college students is consisted of several dimensions, including: professional application ability, professional innovation ability, learning ability, self-management ability, communication and coordination ability, and teamwork ability. A good entrepreneurship education obviously enhances the employment quality of college students, and apparently boosts their employment willingness.

\section{$7 \quad$ References}

[1] Ma, L., Lan, Z.Z., Tan, R. (2020). Influencing factors of innovation and entrepreneurship education based on the theory of planned behavior. International Journal of Emerging Technologies in Learning, 15(13), 190-206. https://doi.org/10.3991/ijet.v15i13.15345

[2] Hua, S.Y., Ren, Z.W. (2020). "Online + Offline" course teaching based on case teaching method: a case study of entrepreneurship education course. International Journal of Emerging Technologies in Learning, 15(10), 69-85. https://doi.org/10.3991/ijet.v15i10 .13999

[3] Cui, J., Sun, J., Bell, R. (2019). The impact of entrepreneurship education on the entrepreneurial mindset of college students in China: The mediating role of inspiration and the role of educational attributes. The International Journal of Management Education, 19(1): 100296. https://doi.org/10.1016/j.ijme.2019.04.001

[4] Chen, H.M., Liang, M. (2020). Empirical analysis on regional economic growth from the perspectives of entrepreneurship and investment in research and development. International Journal of Sustainable Development and Planning, 15(8), 1259-1265. https://doi.org/ $\underline{10.18280 / i j s d p .150812}$

[5] Ding, Y.Y. (2017). The constraints of innovation and entrepreneurship education for university students. Journal of Interdisciplinary Mathematics, 20(6-7): 1431-1434. https://doi.org/10.1080/09720502.2017.1382152 
[6] Xue, L., Cho, Y.J., He, W., Yao, L., Zou, W. (2021). Construction and application of the student satisfaction evaluation system for the extracurricular education services in colleges. Computer Applications in Engineering Education, 29(2): 370-384. https://doi.org/10.1002 /cae.22206

[7] Abdelkarim, A. (2021). From entrepreneurial desirability to entrepreneurial self-efficacy: the need for entrepreneurship education - a survey of university students in eight countries. Entrepreneurship Education, 4(1): 67-88. https://doi.org/10.1007/s41959-021-00046-8

[8] Yan, X. (2021). Employment and Entrepreneurship Education for University Students Based on Improved ACO Algorithm and Embedded Database. Microprocessors and Microsystems, 9: 104087. https://doi.org/10.1016/j.micpro.2021.104087

[9] Somby, H.M., Johansen, V. (2017). Entrepreneurship education: motivation and effort for pupils with special needs in Norwegian compulsory school. European Journal of Special Needs Education, 32(2): 238-251. https://doi.org/10.1080/08856257.2016.1223398

[10] Miao, Y., Fan, H., Yuan, B. (2021). Optimization of supporting college students entrepreneurship environment. Computer Applications in Engineering Education, 29(2): 445-452. https://doi.org/10.1002/cae.22228

[11] Wu, Y.C.J., Wu, T., Li, Y. (2019). Impact of using classroom response systems on students' entrepreneurship learning experience. Computers in Human Behavior, 92: 634-645. https://doi.org/10.1016/j.chb.2017.08.013

[12] Belwal, R., Al Balushi, H., Belwal, S. (2015). Students' perception of entrepreneurship and enterprise education in Oman. Education+ Training. 57(8-9): 924-947. https://doi.org/ 10.1108/ET-12-2014-0149

[13] Boysen, M.S.W., Jansen, L.H., Knage, M. (2020). To share or not to share: a study of educational dilemmas regarding the promotion of creativity and innovation in entrepreneurship education. Scandinavian Journal of Educational Research, 64(2): 211-226. https://doi.org/10.1080/00313831.2018.1531919

Wang, H.L. (2017). Construction of entrepreneurship courses in tibetan agriculture and forestry colleges and universities. Asian Agricultural Research, 9(8): 90-94. https://doi.org/ 10.22004/ag.econ.265382

[15] Pruett, M., Şeşen, H. (2017). Faculty-student perceptions about entrepreneurship in six countries. Education+Training. https://doi.org/10.1108/ET-03-2013-0028

[16] Ibrahim, O.A., Devesh, S., Ubaidullah, V. (2017). Implication of attitude of graduate students in Oman towards entrepreneurship: an empirical study. Journal of Global Entrepreneurship Research, 7(1): 1-17. https://doi.org/10.1186/s40497-017-0066-2

[17] Shah, I.A., Amjed, S., Jaboob, S. (2020). The moderating role of entrepreneurship education in shaping entrepreneurial intentions. Journal of Economic Structures, 9(1): 1-15. https://doi.org/10.1186/s40008-020-00195-4

[18] Westhead, P., Solesvik, M.Z. (2016). Entrepreneurship education and entrepreneurial intention: Do female students benefit? International Small Business Journal, 34(8): 9791003. https://doi.org/10.1177/0266242615612534

[19] Li, W.M., Li, C.Y., Du, X.H. (2016). Ten years of entrepreneurship education at chinese universities: evolution, problems, and system building. Chinese Education \& Society, 49(3): 198-216. https://doi.org/10.1080/10611932.2016.1218250

[20] De Hoyos-Ruperto, M., Pomales-García, C., Padovani, A., Suárez, O.M. (2017). An entrepreneurship education co-curricular program to stimulate entrepreneurial mindset in engineering students. MRS Advances, 2(31): 1673-1679. https://doi.org/10.1557/adv.2017 .109 
[21] Hadi, C., Wekke, I.S., Cahaya, A. (2015). Entrepreneurship and education: creating business awareness for students in East Java Indonesia. Procedia-Social and Behavioral Sciences, 177: 459-463. https://doi.org/10.1016/j.sbspro.2015.02.396

[22] Harkema, S.J., Schout, H. (2012). Incorporating student-centered learning in innovation and entrepreneurship education. IEEE Engineering Management Review, 40(2): 164-174. https://doi.org/10.1109/EMR.2012.6210525

[23] Matlay, H., Gimmon, E. (2014). Mentoring as a practical training in higher education of entrepreneurship. Education+Training, 56(8-9): 814-825. https://doi.org/10.1108/ET-022014-0006

[24] Zhao, S., Zhang, H., Wang, J. (2018). Cognition and system construction of civil engineering innovation and entrepreneurship system in emerging engineering education. Cognitive Systems Research, 52: 1020-1028. https://doi.org/10.1016/j.cogsys.2018.10.020

[25] Fenton, M., Barry, A. (2014). Breathing space-graduate entrepreneurs' perspectives of entrepreneurship education in higher education. Education \& Training, 56(8/9): 733. https://doi.org/10.1108/ET-05-2014-0051

[26] Din, B.H., Anuar, A.R., Usman, M. (2016). The effectiveness of the entrepreneurship education program in upgrading entrepreneurial skills among public university students. Procedia-Social and Behavioral Sciences, 224: 117-123. https://doi.org/10.1016/j.sbspro .2016 .05 .413

[27] Fan, Y., Zhang, X., Qiu, Y. (2013). The state of Entrepreneurship Education in universities in Shanghai, China: A survey from students' perspective. Creative Education, 4(2): 92. https://doi.org/10.4236/ce.2013.42013

[28] Oosterbeek, H., Praag, M.V., Ijsselstein, A. (2010). The impact of entrepreneurship education on entrepreneurship skills and motivation. European Economic Review, 54(3): 442-454. https://doi.org/10.1016/j.euroecorev.2009.08.002

[29] Monfort, S.S., Howe, G.W., Nettles, C.D., Weihs, K.L. (2015). A longitudinal examination of re-employment quality on internalizing symptoms and job-search intentions. Journal of Occupational Health Psychology, 20(1): 50. https://doi.org/10.1037/a0037753

[30] Solesvik, M., Westhead, P., Schyns, B. (2014). Entrepreneurship-Specific Education and Entrepreneurial Intention: Do Female Students Benefit? Available at SSRN 2759196. https://doi.org/10.2139/ssrn.2759196

[31] Chen, C.C., Lin, S.Y., Cheng, C.H., Tsai, C.C. (2012). Service quality and corporate social responsibility, influence on post-purchase intentions of sheltered employment institutions. Research in developmental disabilities, 33(6): 1832-1840. https://doi.org/10.1016/j.ridd .2012 .05 .006

[32] Turner, T., Gianiodis, P. (2018). Entrepreneurship unleashed: Understanding entrepreneurial education outside of the business school. Journal of Small Business Management, 56(1): 131-149. https://doi.org/10.1111/jsbm.12365

[33] Nabi, G., Liñán, F., Kirby, D.A., Ibrahim, N. (2011). The case for (social) entrepreneurship education in Egyptian universities. Education+Training, 53(5): 403-415. https://doi.org/10.1108/00400911111147712

[34] Sudharson, K., Ali, A.M., Sermakani, A.M. (2013). An organizational perspective of knowledge communication in developing entrepreneurship education for engineering students. Procedia-Social and Behavioral Sciences, 73: 590-597. https://doi.org/10.1016/ j.sbspro.2013.02.095

[35] Travaglianti, F., Babic, A., Hansez, I. (2018). Relationships between employment quality and intention to quit: Focus on $\mathrm{PhD}$ candidates as traditional workers. Studies in Continuing Education, 40(1): 115-131. https://doi.org/10.1080/0158037X.2017.1396448 


\section{Authors}

Chunxu Jia is an associate professor working on Hebei Jiaotong Vocational and Technical College. She graduated from Hebei Normal University. Her research interests include education and student management, she has published more than 3 papers published and 1 book published. Email: jia810jia@126.com.

Jialin Zuo is an associate professor working on Hebei Jiaotong Vocational and Technical College. She graduated from Hebei Normal University. Her research interests include education and student management, she has published more than 3 papers published and 1 book published. Email: zuo0616zuo@126.com.

Wei Lu is an associate professor working on Hebei Jiaotong Vocational and Technical College. She graduated from Huaibei Normal University. Her research interests include education and student management, she has published more than 3 papers published and 1 book published. Email: lu0727lu@126.com.

Article submitted 2021-06-18. Resubmitted 2021-07-23. Final acceptance 2021-07-23. Final version published as submitted by the authors. 